\title{
PENGARUH KEERGONOMISAN STASIUN KOMPUTER GAME NET PADA RISIKO GANGGUAN OTOT-RANGKA
}

\author{
Yassierli*, Diaz Abdul Aziiz Irawan, Kartika Kusuma Pratiwi \\ Fakultas Teknologi Industri, Institut Teknologi Bandung, \\ Jl. Ganesha 10 Bandung 40132
}

(Received: January 30, 2018/ Accepted: May 31, 2018)

\begin{abstract}
Abstrak
Maraknya pengguna online game memicu terjadinya peningkatan jumlah penyedia jasa bermain game net dengan pengguna anak-anak, namun stasiun komputer yang digunakan ditujukan untuk pengguna dewasa. Akibatnya, muncul isu ergonomi yang dapat mengakibatkan keluhan otot rangka dengan salah satu indikatornya adalah kelelahan otot rangka. Penelitian ini bertujuan mengetahui pengaruh keergonomisan stasiun komputer game net dan dampaknya terhadap tingkat kelelahan otot jari tangan pada anak-anak pengguna online game. Metode penelitian dilakukan dengan wawancara pengguna game net $(n=166)$, survei keergonomisan game net $(n=18)$ dan dilanjutkan dengan eksperimen. Pada eksperimen, sebanyak 36 anak (usia 12 tahun) direkrut secara random sebagai partisipan dan diminta bermain selama 4 jam di stasiun komputer game net yang dikategorikan ergonomis dan non-ergonomis berdasarkan hasil survei. Pengukuran kelelahan dilakukan menggunakan tiga tes kekuatan otot jari tangan, yakni tip pinch, key pinch, dan palmar pinch secara bergantian untuk tangan kanan dan kiri setiap satu jam. Kelelahan didefiniskan sebagai kecepatan pengurangan dari kekuatan maksimum terhadap waktu. Berdasarkan hasil uji komparasi $t$ berpasangan, disimpulkan bahwa keergonomisan stasiun komputer berpengaruh signifikan terhadap tingkat kelelahan yang diukur melalui tip pinch dan key pinch untuk tangan kanan dan tangan kiri (p<0.05). Hasil penelitian ini menunjukkan pentingnya faktor ergonomi dalam rancangan stasiun komputer game net untuk mencegah gangguan otot-rangka.
\end{abstract}

Kata kunci: Kelelahan; Keluhan otot-rangka; Computer; Ergonomi

\begin{abstract}
[Effect of Non-ergonomic Game Net Computer Station on Risks of Musculockeletal Disorders] The number of game net computer station providing online game has dramatically increased in Indonesia. The majority of game net users are children, but the computer stations are designed for adult users. This study was aimed at determining the effect of non-ergonomic game net computer station and its impact on the development of muscle fatigue on children finger. The study consisted of interview of game net users $(n=166)$, survey of game net condition $(n=18)$, and experiment. In the experiment, a total of 36 children (aged 12 years) were recruited as the participant. They were asked to play at both ergonomic and non-ergonomic game net computers for 4 hours. Fatigue development was measured using strength tests of finger muscle, including tip pinch, key pinch, and palmar pinch alternately for the left and right hands in every hour. Fatigue is defined as the rate of reduction in maximum strength by time. Based on t-paired comparison test, it was concluded that the ergonomics condition of computer stations had significant effect on the level of fatigue of children measured through key tip pinch and pinch for the right hand and left hand ( $p<0.05)$. The results of this study indicated the importance of ergonomic factors in the design of game net computer station in order to prevent complaint at musculoskeletal system.
\end{abstract}

Keywords: Fatigue, Complaint; Musculoskeletal, Computer; Ergonomics

\footnotetext{
*) Penulis Korespondensi.

e-mail: yassierli@mail.ti.itb.ac.id
} 


\section{Pendahuluan}

Saat ini jumlah pengguna online game di Indonesia terus meningkat. Data tahun 2014 menunjukkan bahwa pengguna online game di Indonesia hampir 20 juta orang, dengan nilai bisnis hampir Rp 1,2 Trilyun (Baskoro, 2014). Segmen terbesar pengguna online game adalah anak-anak dan remaja. Meskipun penggunaan perangkat mobile semakin meningkat, namun sebagian besar pengguna online game masih menggunakan komputer desktop, baik melalui akses internet komputer pribadi di rumah atau melalui warung internet yang khusus menawarkan online game yang disebut juga game net. Bisnis penyedia jasa ini semakin marak karena harga sewa per jam yang ditawarkan terjangkau oleh anak-anak sehingga menimbulkan potensi kecanduan bagi penggunanya.

Potret game net yang ada di Indonesia saat ini menunjukkan bahwa stasiun komputer tidak dirancang untuk anak-anak, melainkan untuk dewasa. Ketidaksesuaian antara dimensi stasiun komputer orang dewasa dengan dimensi tubuh anak-anak akan memicu pengadopsian posisi tubuh yang kurang baik yang dapat berdampak pada terjadinya kelainan sistem otot rangka pada anak (Ciccarelli dkk., 2012; Harris dkk., 2015). Seperti halnya pada orang dewasa, anakanak juga mengalami musculoskeletal discomfort akibat penggunaan stasiun komputer (Jacobs dkk., 2009; Straker dkk., 2010). Beberapa penelitian menunjukkan bahwa penggunaan komputer untuk bermain game mendorong munculnya lebih banyak sikap kerja yang tidak ergonomis dan konsentrasi yang intens pada anak-anak dibandingkan dengan melakukan aktivitas lainnya (Straker dkk, 2010). Selain itu, penggunaan stasiun kerja komputer yang tidak ergonomis pada anak-anak mengakibatkan gangguan pada kepala, leher dan bahu, serta punggung bagian bawah (Kimmerly \& Odell, 2009; Harris dkk., 2012; Sellschop, 2010). Dalam jangka panjang, keluhan pada sistem otot rangka tersebut dapat menurunkan kemampuan kerja, produktivitas kerja, dan dampak kelainan pada sistem otot rangka yang lebih besar, seperti cedera kronis, penghentian pertumbuhan tulang, deformasi tulang, hingga cacat permanen (Pate, 2011).

Salah satu upaya pencegahan terjadinya kelainan sistem otot rangka anak-anak yang bermain online game adalah melalui penerapan ergonomi pada rancangan game net dengan memperhatikan antropometri anak-anak. Penelitian terkait dengan stasiun kerja komputer ergonomis untuk anak-anak telah dilakukan oleh beberapa peneliti terdahulu, seperti studi antropometri stasiun komputer untuk anak-anak sekolah dasar (Oyewole dkk., 2010), studi pengujian kesesuaian antara dimensi stasiun komputer dengan dimensi tubuh anak-anak (Yanto dkk., 2017; Castellucci dkk., 2010; Castellucci., 2017), studi identifikasi kesesuaian dimensi stasiun komputer dengan tubuh anak-anak disertai rekomendasi acuan pengukuran antropometri (Dianat dkk., 2013), dan studi mengenai pengaruh penggunaan stasiun kerja ergonomis pada gejala kelainan sistem otot rangka anak-anak sekolah dasar (Saarni dkk., 2015). Namun sayangnya, masih sedikit penelitian yang membahas dampak ketidakergonomisan stasiun kerja komputer anak-anak (Straker, 2010), khususnya game net yang semakin menjamur di Indonesia.

Rancangan stasiun kerja komputer game net terdiri dari tata letak monitor, keyboard, mouse serta dimensi meja dan kursi yang merupakan komponen fisik yang berinteraksi langsung dengan anak-anak selama bermain online game. Ketika rancangan yang ada ditujukan untuk orang dewasa digunakan anak-anak, anak-anak tentu akan memaksakan sikap tubuh mereka agar dapat tetap menggunakan komputer. Dampaknya, berbagai sikap duduk yang tidak ergonomis akan terjadi, misalnya: kaki menggantung, bahu terangkat, pergelangan tangan menekuk, leher mendongak, punggung bawah tidak tersangga, dan lain-lain. Semua sikap tubuh tersebut merupakan faktor risiko terhadap gangguan sistem otot rangka, terlebih jika sikap tubuh tersebut terpapar terus menerus seiring dengan semakin candunya anak-anak terhadap online game. Salah satu instrumen yang dapat digunakan untuk penilaian kondisi keergonomisan stasiun komputer adalah dengan menggunakan panduan evaluasi dari OSHA (OSHA, n.d).

Karakteristik aktivitas di stasiun komputer telah dikaitkan dengan Low Frequency Fatigue (LFF) yang juga merupakan penyebab terjadinya kelainan sistem otot rangka pada pengguna komputer (Kim \& Jhonson, 2014). Kelelahan merupakan salah satu indikator proxy (surrogate measure) gangguan sistem otot rangka (Yassierli \& Nussbaum, 2009). Kelelahan terjadi karena beban kerja (termasuk salah satunya tuntutan sikap tubuh) melebihi kapasitas individu. Semakin tidak ergonomis suatu aktivitas, maka semakin besar tingkat kelelahannya. Berbagai studi telah menggunakan kelelahan sebagai indikator keergonomisan suatu sistem kerja (Yassierli \& Nussbaum, 2009). Pada penelitian ini, tingkat kelelahan juga digunakan sebagai indikator ketidakergonomisan stasiun kerja komputer online game. Tujuan penelitian ini adalah untuk membandingkan tingkat kelelahan otot jari tangan pada anak-anak pengguna online game saat menggunakan stasiun komputer yang ergonomis dan non-ergonomis. Hipotesis penelitian ini adalah stasiun kerja yang tidak ergonomis mengakibatkan kelelahan yang lebih besar dan berujung pada meningkatnya risiko gangguan sistem otot rangka.

\section{Bahan dan Metode}

Penelitian ini diawali dengan wawancara pengguna game net $(\mathrm{n}=166$ anak) untuk mengetahui profil demografi dan kebiasaan mereka. Setelah wawancara, dilakukan survei terhadap 18 game net di sekitar daerah kampus ITB Bandung menggunakan panduan evaluasi 10 kriteria dari OSHA (OSHA, n.d) untuk mengetahui keergonomisan rancangan stasiun 
komputer yang digunakan di game net. Sepuluh kriteria penilaian tersebut adalah:

1. Sandaran punggung menopang punggung bawah terutama lumbar

2. Tebal dan kedalaman tempat duduk dapat mengakomodasi pengguna tanpa menekan belakang lutut

3. Sandaran lengan, jika digunakan, mampu menopang lengan bawah ketika menggunakan komputer dan tidak mengganggu pergerakan

4. Alas keyboard dan peralatan masukan stabil dan cukup besar untuk menopang papan tombol dan peralatan masukan

5. Mouse dan sejenisnya berada di samping keyboard dengan bentuk/ ukuran sesuai dengan pengguna sehingga dapat digunakan tanpa harus menjangkau

6. Pergelangan tangan lurus dan tidak diletakan pada permukaan berujung tajam dan keras

7. Bagian atas layar monitor berada sejajar dengan ketinggian mata dengan posisi monitor tepat di depan pengguna tanpa harus memutar kepala atau leher

8. Jarak monitor sesuai untuk membaca layar tanpa harus memajukan tubuh

9. Tidak ada silau dari monitor yang dapat mengakibatkan postur janggal dalam melihat monitor

10. Serta paha dan kaki memiliki ruang yang cukup di bagian bawah meja yang telah dibahas di atas.

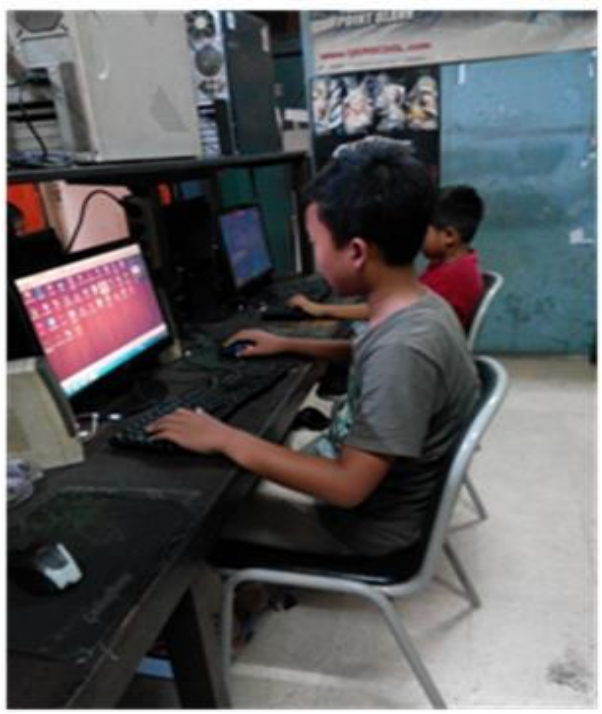

Dari 18 game net yang disurvei dipilih 1 stasiun komputer yang paling ergonomis dan 1 yang paling tidak ergonomis (Gambar 1).

Eksperimen dilakukan di kedua game net tersebut untuk mengetahui pengaruh keergonomisan stasiun komputer terhadap kelelahan otot jari tangan anakanak pengguna online game. Sebanyak 36 anak (semuanya laki-laki dan tidak kidal) direkrut secara acak sebagai partisipan dalam eksperimen. Mereka adalah pengunjung game net. Partisipan yang dipilih berusia 12 tahun (sesuai dengan hasil survei), telah berpengalaman bermain online game minimal selama 1 tahun, dan dipastikan tidak pernah mengalami kelainan pada sistem otot rangka.

Eksperimen bersifat within-subject design dimana partisipan mengalami dua perlakukan atau kondisi, yaitu pada kondisi stasiun kerja ergonomis dan nonergonomis. Hipotesis kami adalah kelelahan akan lebih tinggi pada stasiun kerja yang tidak ergonomis. Setiap partisipan diminta bermain online game selama 4 jam di dua hari yang berbeda. Pemilihan 4 jam sesuai dengan hasil survei. Pengukuran kekuatan ototjari dilakukan sebelum bermain dan setiap 1 jam menggunakan hydraulic pinch gauge. Tiga pengukuran yang dilakukan adalah tip pinch, key pinch, dan palmar pinch masing-masing untuk tangan kanan dan kiri mengacu pada penelitian McQuiddy dkk., (2015) dan dilakukan sesuai Gambar 2. Prosedur pengukuran yang dilakukan adalah partisipan duduk dengan posisi bahu netral dan tidak terangkat, dan mereka diminta untuk melakukannya sekuat tenaga tanpa sentakan.

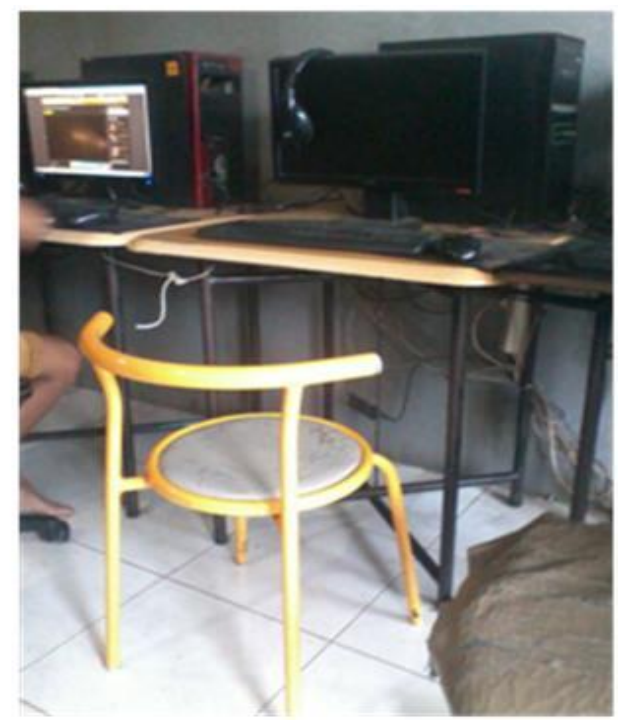

Gambar 1. Stasiun Kerja paling Ergonomis (kiri) dan Stasiun Kerja paling Tidak Ergonomis (kanan) 


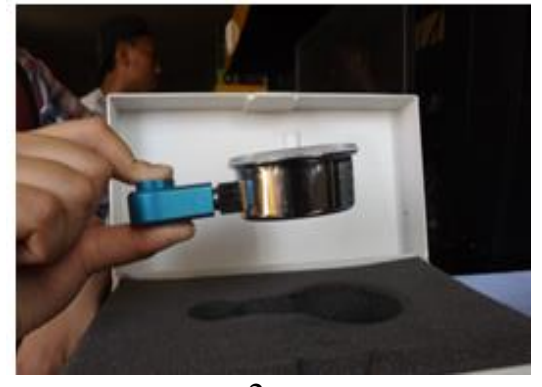

2.a

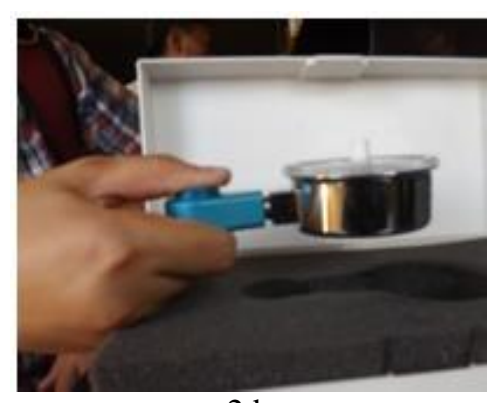

2.b

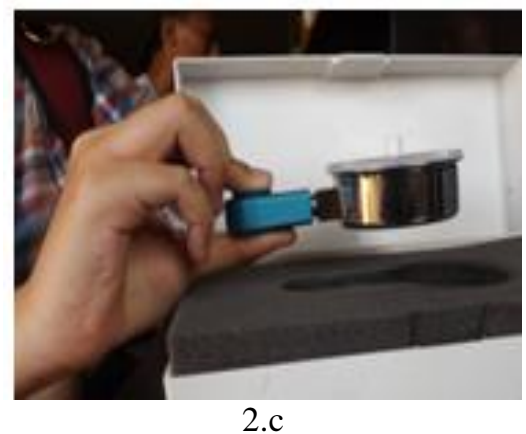

Gambar 2. Posisi Tangan saat Pengukuran Kekuatan (2.a) Tip Pinch, (2.b) Key Pinch, dan (2.c) Palmar Pinch

Data survei diolah secara statistika deskriptif terkait dengan sebaran usia dan durasi waktu bermain, sedangkan data eksperimen diolah secara statistika inferensial. Variabel bebas adalah jenis stasiun komputer (ergonomis dan non-ergonomis). Variabel terikat adalah tingkat kelelahan yang diukur melalui 3 metode pengukuran kekuatan melalui tangan kanan dan tangan kiri. Kelelahan didefiniskan sebagai pengurangan kekuatan dari nilai awal (pengukuran awal). Data setiap individu dianalisis berdasarkan perubahan terhadap waktu untuk setiap metode pengukuran kekuatan (terdapat 5 kali pengukuran). Tingkat kelelahan dihitung sebagai slope pengurangan kekuatan dari nilai awal yang didekati dengan regresi linier. Nilai slope menggambarkan laju penurunan kekuatan otot jari tangan. Uji beda dilakukan menggunakan uji komparasi t-berpasangan.

\section{Hasil dan Pembahasan \\ Hasil}

Hasil wawancara terhadap sebaran usia pengguna online game dari 18 game net dapat dilihat pada Gambar 3. Terlihat bahwa sebagian besar usia pengguna $(\mathrm{n}=166)$ online game adalah anak-anak usia 12 tahun. Terkait dengan lama bermain, sebagian besar anak-anak menghabiskan waktu selama 3 jam di game net. Hasil survei keergonomisan 18 game net merekomendasikan pilihan game net yang paling ergonomis dan paling tidak ergonomis. Namun, karena kondisi stasiun komputer yang paling ergonomis masih jauh dari standar panduan ketika digunakan oleh anak- anak, beberapa intervensi dilakukan untuk mendapatkan kondisi stasiun komputer yang lebih ergonomis, meliputi penambahan ketinggian alas duduk sehingga tepi atas monitor berada sejajar dengan ketinggian mata, penambahan sandaran kaki dan penambahan sandaran punggung.
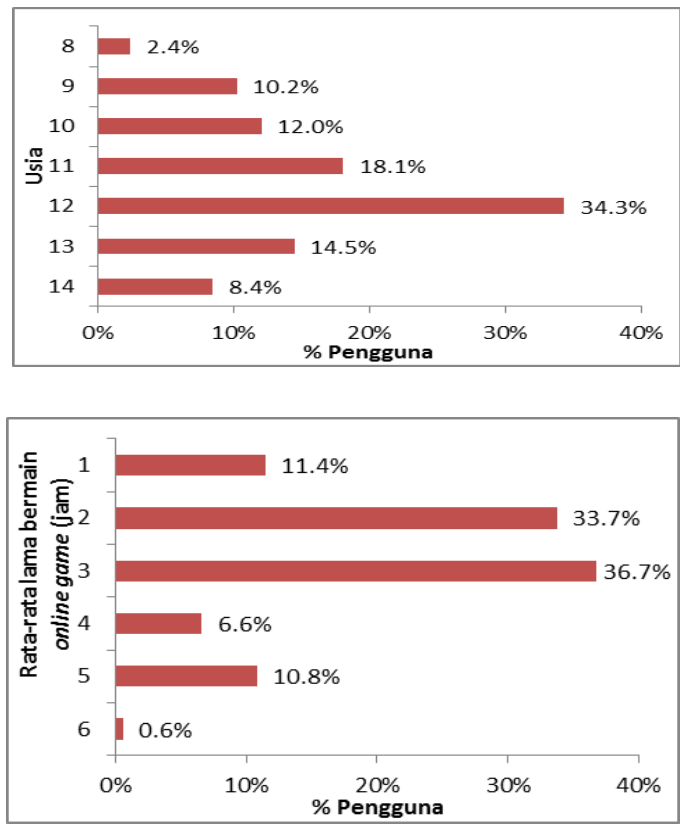

Gambar 3. Hasil Survei terkait Usia Anak-Anak dan Rata-Rata Lama Bermain Online Game (Sampel = 166) 
Data demografi 36 partisipan adalah sebagai berikut: rata-rata usia 12 tahun, pengalaman bermain online game rata-rata 2,61 tahun (simpangan baku: 1,14 tahun), frekuensi bermain online game perminggu rata-rata: 2,36 kali (simpangan baku: 0,61), dan lamanya bermain online game, rata-rata: 3,06 jam (simpangan baku: 1,0). Contoh hasil pengukuran dari satu orang partisipan saat menggunakan stasiun komputer ergonomis dan nonergonomis untuk key pinch tangan kanan dapat dilihat pada Gambar 4.

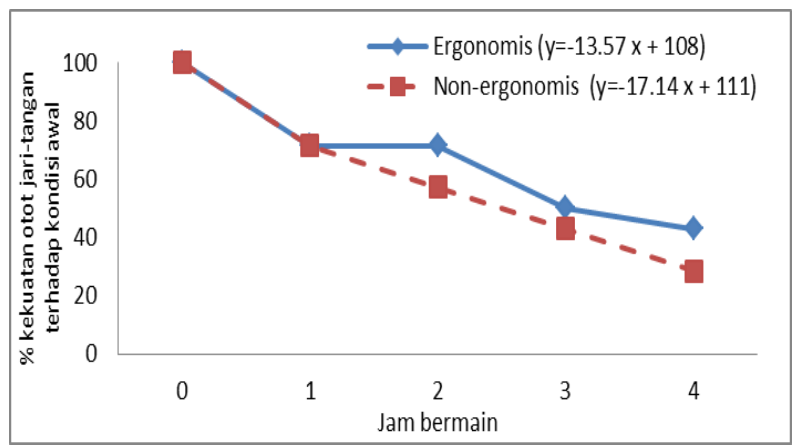

Gambar 4. Contoh Individual Data Hasil Pengukuran Kekuatan Key Pinch Tangan Kanan

Secara keseluruhan, laju kelelahan otot jari tangan saat bermain online game pada stasiun komputer ergonomis adalah $8 \%$ perjam dan pada stasiun komputer non-ergonomis adalah $10 \%$ perjam (Gambar 5). Hasil uji komparasi berpasangan menunjukkan bahwa terdapat perbedaan yang signifikan pada tingkat kelelahan otot jari tangan saat menggunakan stasiun komputer ergonomis dan non-ergonomis untuk tip pinch dan key pinch, tetapi tidak untuk palmar pinch. Hasil uji tberpasangan terhadap data key pinch test tangan kanan menunjukkan nilai signifikansi $0,031 \quad(\mathrm{p}<0,05)$ yang mengindikasikan adanya pengaruh penggunaan stasiun kerja ergonomis dan non-ergonomis terhadap kelelahan. Pada tip pinch kanan, laju kelelahan otot jari tangan saat bermain online game pada stasiun komputer nonergonomis 1,8 kali lebih tinggi dibandingkan saat menggunakan stasiun komputer ergonomis. Pada tip pinch kiri, perbedaan laju kelelahan otot jari tangan antara stasiun komputer non-ergonomis dan ergonomis lebih rendah yakni 1,2 kali lebih tinggi, tapi perbedaan tetap signifikan.
Hasil pengukuran kelelahan menggunakan key pinch menunjukkan bahwa laju kelelahan otot jari tangan saat bermain online game pada stasiun komputer nonergonomis juga signifikan lebih tinggi dibandingkan saat menggunakan stasiun komputer non-ergonomis. Perbedaannya $7 \%$ dan $43 \%$ untuk tangan kanan dan tangan kiri secara berurutan. Hasil yang berbeda diperoleh saat pengukuran kelelahan dilakukan menggunakan palmar pinch, dimana perbedaan hasil antara kedua stasiun komputer tidak signifikan.

Perbedaan penurunan nilai tip pinch pada tangan kanan lebih besar dibandingkan pada tangan kiri karena aktivitas tangan.

\section{Pembahasan}

Penelitian ini bertujuan untuk mengetahui pengaruh keergonomisan stasiun komputer game net terhadap tingkat kelelahan pada anak-anak pengguna online game. Tingkat kelelahan tidak diukur secara subjektif untuk menghindari bias karena partisipan merupakan anak-anak yang cenderung belum mengerti mengenai kriteria penilaian. Laju tingkat kelelahan diukur menggunakan alat ukur pinch grip test yang berfokus pada kekuatan otot jari tangan yang relevan dengan aktivitas bermain online game yang didominasi oleh aktivitas jari tangan untuk mengoperasikan keyboard maupun mouse. Hal ini juga sesuai dengan pandangan beberapa peneliti dalam peninjauan ulang yang dilakukan oleh Kim \& Johnson (2014) yang menyatakan bahwa penggunaan komputer lebih berkaitan dengan musculoskeletal symptoms pada tangan dan lengan (Kim \& Johnson, 2014). Hasil pengujian kelelahan dengan menggunakan indikator tip pinch dan key pinch menunjukkan bahwa keergonomisan stasiun komputer berpengaruh signifikan terhadap tingkat kelelahan anakanak. Bermain online game di stasiun komputer nonergonomis menyebabkan laju tingkat kelelahan meningkat dibandingkan stasiun komputer yang ergonomis.

Tip pinch test dilakukan untuk mengukur kekuatan otot tangan dan jari melalui penekanan ibu jari pada ujung telunjuk. Hasil uji kekuatan tip pinch tangan kanan maupun tangan kiri menunjukkan bahwa keergonomisan stasiun kerja mempengaruhi tingkat kelelahan. Tingkat kelelahan lebih tinggi saat partisipan bermain online game di stasiun komputer nonergonomis. 


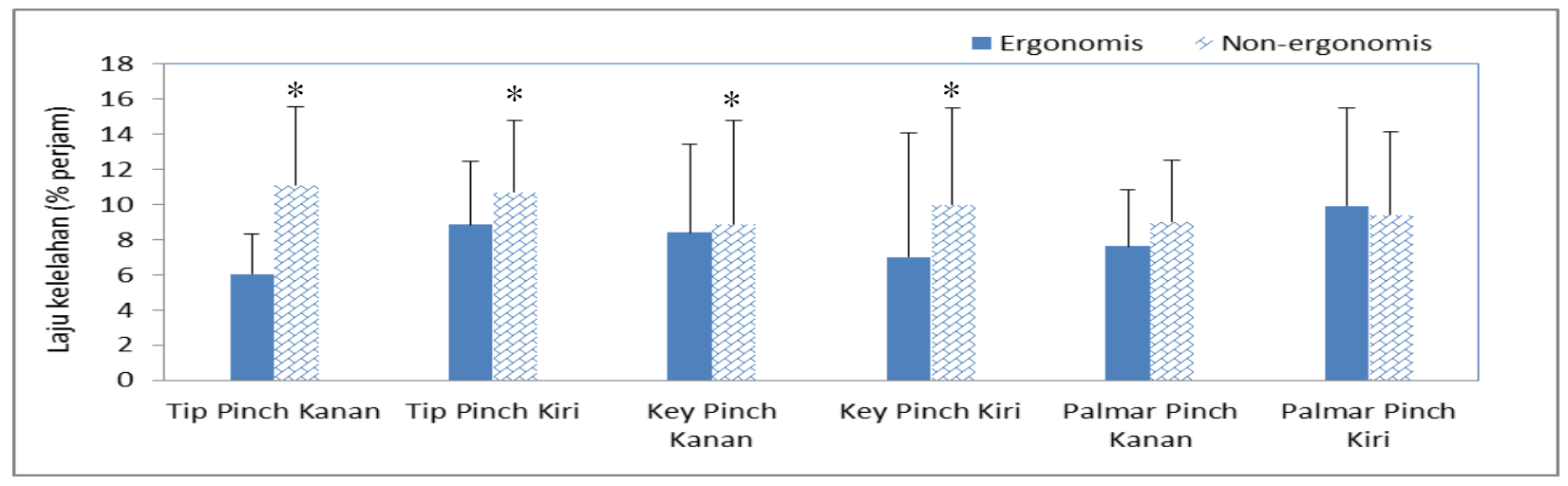

Gambar 5. Perbandingan Laju Kelelahan (\% /jam) Hasil Berbagai Pengukuran. Tanda * Menunjukkan Perbedaan Signifikan dengan $p<0,05$

Perbedaan penurunan nilai tip pinch tangan kanan pada stasiun kerja ergonomis dan non-ergonomis terjadi karena adanya intervensi ergonomi yang dilakukan melalui penambahan alas duduk di stasiun kerja ergonomis. Hal ini menyebabkan posisi siku ketika bermain online game membentuk sudut $90^{\circ}$ sehingga lengan bawah dan pergelangan tangan berada pada posisi netral. Hal ini sesuai dengan penelitian sebelumnya yang menyatakan bahwa posisi mouse dan keyboard harus diletakkan berdekatan dan harus memberikan posisi netral pada lengan dan pergelangan tangan (posisi lengan atas dalam keadaan rileks dan pergelangan tangan dalam keadaan lurus) serta siku membentuk sudut $90^{\circ}$ (Travail, 2010; Sonnea dkk., 2012). Posisi netral pada stasiun komputer yang ergonomis akan meminimasi kelelahan pada lengan dan pergelangan tangan.

Pada stasiun kerja non-ergonomis, mouse diletakkan di atas permukaan meja setinggi $75 \mathrm{~cm}$ dan sulit dijangkau oleh anak-anak. Letak mouse tersebut mengakibatkan lengan atas dan lengan bawah terangkat serta terjadi penekanan pada pergelangan tangan, sehingga kontraksi otot yang terjadi lebih besar. Kontraksi otot yang berlangsung lama dan terus menerus ini akan mengakibatkan kelelahan pada otot (Kim \& Johnson, 2014).

Key pinch test dilakukan untuk mengukur kekuatan otot tangan dan jari melalui penekanan ibu jari pada sisi radial telunjuk. Signifikansi hasil key pinch test dapat dijelaskan melalui pengamatan pada aktivitas ibu jari tangan selama bermain online game. Aktivitas yang dilakukan oleh ibu jari saat bermain online game adalah menggenggam mouse secara terus menerus selama 4 jam. Walaupun cenderung statis, namun aktivitas ini mengakibatkan terjadinya kelelahan pada ibu jari dan dapat menimbulkan trauma minor yang bersifat repetitif pada ibu jari yang menyebabkan malfungsi pada tendon sheaths (Sellschop, 2010). Selain itu, sisi radial jari telunjuk juga mengalami kelelahan akibat aktivitas jari telunjuk yang dominan saat bermain online game sehingga sebagai penopang pada saat pengukuran, kekuatan penekanan juga akan dipengaruhi oleh kekuatan sisi radial jari telunjuk.

Palmar pinch test dilakukan untuk mengukur kekuatan otot tangan dan jari melalui penekanan telunjuk dan jari tengah pada ibu jari. Indikator ini tidak dipengaruhi secara signifikan oleh keergonomisan stasiun komputer. Selama bermain online game, tidak banyak aktivitas yang dilakukan oleh jari tengah juga ibu jari, sehingga walaupun jari telunjuk mengalami kelelahan lokal, namun jari tengah akan memberikan kekuatan yang lebih pada palmar pinch test, baik tangan kiri maupun kanan. Hasil ini sejalan dengan penelitian yang dilakukan oleh Juraida (2014) yang menyatakan bahwa palmar pinch test tidak sensitif dalam mengukur kelelahan.

Hasil penelitian menunjukkan pentingnya perancangan stasiun komputer game net secara ergonomis dengan mempertimbangkan antropometri anak-anak serta postur bermain. Desain stasiun komputer dengan mengacu pada pengukuran antropometri penting dilakukan (Dianat dkk., 2013) untuk menghasilkan rancangan stasiun kerja yang ergonomis yang dapat mengurangi kelelahan dan ketidaknyamanan dalam posisi postur kerja duduk (Agha, 2010). Desain stasiun kerja menurut Straker dkk., (2010) juga penting untuk diperhatikan karena stasiun kerja yang ergonomis akan mendukung pengaplikasian postur kerja yang baik seperti yang terjadi pada penelitian ini.

Penelitian ini hanya melibatkan partisipan anak-anak pada game net dengan radius lokasi berjarak $5 \mathrm{~km}$ dari ITB sehingga hasil penelitian belum merepresentasikan populasi pengguna game net di Kota Bandung serta tidak menggambarkan karakteristik anak-anak pengguna online game yang lebih luas. Selain itu, pemilihan stasiun kerja ergonomis dan non-ergonomis dilakukan dengan menggunakan evaluation checklist OSHA, namun hanya melibatkan komponen-komponen yang relevan dengan penilaian stasiun kerja ergonomis dan 
mengabaikan penilaian sikap kerja. Penelitian selanjutnya diharapkan dapat mengkaji postur anak-anak saat bermain game online untuk memperoleh informasi yang dapat digunakan dalam perbaikan desain stasiun komputer non-ergonomis.

\section{Kesimpulan}

Penelitian ini bertujuan untuk mengetahui pengaruh penggunaan stasiun kerja ergonomis dan non-ergonomis terhadap kelelahan yang dialami oleh anak-anak pengguna game net saat bermain online game. Berdasarkan hasil pengukuran pinch grip test, dapat disimpulkan bahwa keergonomisan stasiun komputer selama bermain online game dapat berpengaruh terhadap tingkat kelelahan otot jari tangan anak-anak. Hasil penelitian juga menunjukkan bahwa dari indikator yang digunakan, tip pinch tangan kanan merupakan indikator yang paling tepat untuk mengukur tingkat kelelahan.

Desain stasiun komputer online game untuk anakanak yang ada saat ini pada umumnya tidak sesuai dengan antropometri anak-anak. Mengingat lamanya waktu bermain, kedepannya perancangan stasiun komputer harus disesuaikan dengan antropometri tubuh anak-anak serta postur bermain sehingga risiko kelelahan dan kelainan otot rangka dapat dikurangi. Penelitian terhadap faktor durasi waktu juga dapat dilakukan untuk memperoleh kesimpulan yang lebih menyeluruh.

\section{Daftar Pustaka}

Agha, S.R. (2010). School furniture match to student anthropometry in the Gaza Strip. Ergonomics, 53, 344-354.

Baskoro, R. (2014). Game Online Indonesia Tahun 2014. Diakses 15 Juni 2015. Diunduh dari: http://www.duniaku.net/2015/02/20/game-onlineindonesia-tahun-2014-ikhtisar-dan-infografis.

Castellucci, H. I., Arezes, P. M., \& Viviani, C. (2010). A. Mismatch between Classroom Furniture and Anthropometric Measures in Chilean Schools. Applied Ergonomics, 41(4), 563-568.

Castellucci, H. I., Arezes, P. M., Molenbroek, J. F. M., de Bruin, R. \& Viviani, C. (2017). The Influence of School Furniture on Students' Performance and Physical Responses: Results of a Systematic Review. Ergonomics, 60(1), 93-110.

Ciccarelli, M., Portsmouth, L., Harris, C., \& Jacobs, K. (2012). Promoting Healthy Computer Use among Middle School Students: A Pilot School-based Health Promotion Program. Work, 41(1),851-856.

Dianat, I., Karimi, M. A., Hashemi, A. A., \& Bahrampour, S. (2013). Classroom Furniture and Anthropometric Characteristics of Iranian High School Students: Proposed Dimensions Based on
Anthropometric Data. Applied Ergonomics, 44, 101108.

Harris, C., Straker, L., Smith, A., \& Pollock, C. (2012). A Proposed Model Representing the Relationships between User Characteristics, Computer Exposure and Musculoskeletal Symptoms in Children. Work, 41(1), 838-845.

Harris, C., Straker, L., Pollock, C., \& Smith, A. (2015). Children, Computer Exposure and Musculoskeletal Outcomes: the Development of Pathway Models for School and Home Computer-related Musculoskeletal Outcomes. Ergonomics, 58(10), 1611-1623.

Jacobs, K., Hudak, S., \& McGiffert, J. (2009). Computer-related Posture and Musculoskeletal Discomfort in Middle School Students. Work. 32(3), 275-283.

Juraida, A. (2014). Pengaruh Jenis dan Posisi Penggunaan Komputer Portabel Terhadap Kelelahan Otot Ekstrimitas Atas dan Mata. Tesis. Bandung: Institut Teknologi Bandung.

Kim, J. H. \& Johnson, P. W. (2014). Fatigue Development in The Finger Flexor Muscle Differs Between Keyboard and Mouse Use. European Journal of Applied Physiological, 114, 2469-2482.

Kimmerly, L., \& Odell, D. (2009). Children and Computer Use in the Home: Workstations, Behaviors and Parental Attitudes. Work, 32(3), 299310 .

McQuiddy, V. A., Scheerer, C. R., Lavalley, R., McGrath, T., \& Lin, L. (2015). Normative Values for Grip and Pinch Strength for 6- to 19-Year-Olds. Archives of Physical Medicine and Rehabilitation, 96(6), 1627-1633.

OSHA. n.d. Computer Workstation Checklist. Diakses 15 Juni 2015. Diunduh dari: https://www.osha.gov/SLTC/etools/computerworkst ations/checklist_evaluation.html.

Oyewole, S. A., Haight, J. M., \& Freivalds, A. (2010). The Ergonomic Design of Classroom Furniture/Computer Work Station for First Graders in the Elementary School. International Journal of Industrial Ergonomics, 40(4), 437-447.

Pate, D. (2011). Growing Bodies: Pediatric Muscloskeletal Injuries in Children. Diakses 20 Januari 2015. Diunduh dari: http://www.toyourhealth.com/ mpacms/tyh/ article.php?id=1380.

Saarni, L. A., Rimpela, A. H., Nummi, T. H., Kaukiainen. A., Salminen. J. J., \& Nygard, C. (2009). Do Ergonomically Designed School Workstation Decrease Musculoskeletal Symptoms in Children? A 26-month Prospective Follow-up Study. Applied Ergonomics, 40, 491-499.

Sellschop, I. (2010). The Association of Computer Use and Musculoskeletal Pain in Schoolchildren Worldwide: What is being Done in the Way of 
Ergonomic Intervention Programs?. Journal of Physical Therapy. 2(1), 38-40.

Sonnea, M., Villaltab, D.L., \& Andrewsa, D. M. (2012). Development and Evaluation of an Office Ergonomic Risk Checklist: ROSA - Rapid Office Strain Assessment. Applied Ergonomics, 43(1), 98108.

Straker, L., Maslen, B., Burgress-Limerick, R., Johnson, P., \& Dennerlein, J. (2010). Evidence-based Guidelines for the Wise Use of Computers by Children: Physical Development Guidelines. Ergonomics, 53(4), 458-477.
Travail, S. (2010). Office Ergonomics: Guidelines for Preventing Musculoskeletal Injuries. Grand BayWestfield: Travail Securitaire.

Yanto, Lua, C. W., \& Lub, J. M. (2017). Evaluation of the Indonesian National Standard for Elementary School Furniture Based on Children's Anthropometry. Applied Ergonomics, 62, 168-181.

Yassierli \& Nussbaum, M. A. (2009). Effects of Age, Gender, and Task Parameters on Fatigue Development during Intermittent Isokinetic Torso Extensions. International Journal of Industrial Ergonomics, 39, 185-191. 